\title{
Analisis Penentuan Infrastruktur Prioritas pada Kawasan Kumuh Lingkungan Kerantil Kota Blitar
}

\author{
Ashar Annas ${ }^{a)}$, Ria Asih Aryani Soemitro ${ }^{\text {b) }}$ \& Eko Budi Santosoc)
}

\begin{abstract}
Data update from Public Works and Housing Ministry records the existence of slum area in Kerantil District, Blitar City. Blitar City government has tried to address slum problem in that district, but until now slum improvement programs still not showing significant result. Based on the existing condition, research on priority infrastructure is conducted in Kerantil slum area, Blitar City. The aim of this research is to address proper program response for Kerantil slum area, Blitar City. This research begins with determining factors causing slum in Kerantil slum area using Confirmatory Factor Analysis. After the factors are determined, infrastructure response priority is determined by means of Service and quality (servqual) Analysis and Importance Performance Analysis (IPA) by comparing the level of importance and performance about infrastructure in slum area based on respondent answer. Several factors causing slum in that area are street infrastructure, drainage infrastructure, water infrastructure, waste infrastructure, building infrastructure, fire protection infrastructure, and green open space infrastructure. The other factors are government role, social, economy, society, and legality. The prioritized infrastructure in Kerantil slum area are waste infrastructure, fire protection infrastructure, and green open space infrastructure.
\end{abstract}

keywords: slum area, causing slum factors, confirmatory factor analysis, priority infrastructure, servqual analysis, importance performance analysis, Kerantil Blitar City.

Abstrak: Berdasarkan pemutakhiran data dari Kementerian PU, Lingkungan Kerantil merupakan salah satu kawasan di Kota Blitar yang ditetapkan sebagai kawasan permukiman kumuh. Terdapat beberapa program pemerintah dilakukan guna mengatasi permasalahan kekumuhan. Namun hingga saat ini program tersebut belum mampu mengatasi kekumuhan di Lingkungan Kerantil. Berdasarkan kondisi di atas maka dilakukan penelitian yang bertujuan untuk menentukan infrastruktur yang diprioritaskan untuk segera ditangani di kawasan kumuh Lingkungan Kerantil Kota Blitar secara tepat. Adapun metode yang digunakan adalah teknik analisis Confirmatory Factor Analisys (CFA) yang digunakan untuk mengetahui faktor-faktor yang secara terkonfirmasi menjadi penyebab kekumuhan di kawasan tersebut. Untuk menemukan infrastruktur-infrastruktur yang diprioritaskan untuk dilakukan penanganan dilakukan dengan menggunakan teknik analisis Service and Quality (Servqual) dan Importance-Performance Analysis (IPA) dengan cara membandingkan antara tingkat kepuasan dan harapan dari responden terhadap infrastruktur pada kawasan tersebut. Beberapa faktor penyebab terjadinya kekumuhan yang ditemukan pada kawasan tersebut antara lain infrastruktur jalan, infrastruktur drainase, infrastruktur air bersih, infrastruktur persampahan, kondisi fisik bangunan, proteksi pemadam kebakaran, dan ruang terbuka hijau. Selain dari faktor infrastruktur, ditemukan pula faktor lain diantaranya peran pemerintah, sosial, ekonomi, peran masyarakat, dan legalitas. Sedangkan infrastruktur yang diprioritaskan untuk mendapatkan penanganan antara lain infrastruktur persampahan, proteksi pemadam kebakaran, dan RTH.

Kata Kunci: Kawasan kumuh, faktor penyebab kekumuhan, confirmatory factor analysis, infrastruktur prioritas, analisis servqual, analisis IPA Lingkungan Kerantil Kota Blitar.

\section{PENDAHULUAN}

Permukiman kumuh merupakan keadaan lingkungan hunian dengan kualitas yang sangat tidak layak huni, dengan ciri-ciri antara lain kepadatan bangunan sangat tinggi dalam luasan yang sangat terbatas, rawan penyakit sosial dan penyakit lingkungan, serta kualitas bangunan yang sangat rendah, tidak terlayaninya prasarana lingkungan yang memadai dan membahayakan keberlangsungan kehidupan dan penghidupan

aPersonnel at Dinas PU dan Penataan Ruang Kota Blitar and a student in the Department of Civil Engineering, Sepuluh Nopember Institute of Technology (ITS), ITS Campus, Sukolilo, Surabaya 60111, Indonesia. Email: nazzplan@gmail.com

b Lecturer in the Department of Civil Engineering, Sepuluh Nopember Institute of Technology (ITS), ITS Campus, Sukolilo, Surabaya 60111, Indonesia. Email: ria@ce.its.ac.id

${ }^{c}$ Lecturer in the Department of Urban and Regional Planning, Sepuluh Nopember Institute of Technology (ITS), ITS Campus, Sukolilo, Surabaya 60111, Indonesia. Email: ekobudis@ hotmail.com

Note. The manuscript for this paper was submitted for review and possible publication on Januari 4, 2018. This paper is part of the ITS Journal of Civil Engineering, Vol. 33, No. 2, November 2018. (C) ITS Journal of Civil Engineering, ISSN 2579-9029/2017. penghuninya [1]. Menurut hasil pemutakhiran data kawasan kumuh yang telah dilaksanakan oleh Kementerian PU Direktorat Pengembangan Permukiman, teridentifikasi dua lokasi kawasan kumuh yang berada di Kelurahan Sukorejo Kecamatan Sukorejo Kota Blitar.

Kelurahan Sukorejo memiliki luas wilayah keseluruhan sebesar 147 hektar dan sebesar 10.75 hektar merupakan RW kumuh dengan penduduk sekitar 4.672 jiwa [2]. Jumlah Rukun Warga (RW) Keseluruhan di Kelurahan Sukorejo berjumlah 14 RW dengan jumlah RW kumuh sebanyak 3 RW. RW dengan klasifikasi permukiman kumuh ringan sejumlah 1 buah (RW 6) dan klasifikasi kumuh sedang sejumlah 2 buah (RW 2 dan RW 3) [3]. Kawsan kumuh pada kelurahan tersebut dikenal dengan sebutan Lingkungan Kerantil.

Lingkungan Kerantil merupakan kawasan kumuh di Kota Blitar yang memerlukan penanganan dengan tepat. Selain karena kawasan tersebut terletak di pusat kota yang merupakan kawasan pusat perekonomian, kawasan tersebut juga terletak di bantaran sungai. Berdasarkan survei awal dari parameter fisik bangunan, dua lokasi yang ditetapkan sebagai lokasi kawasan kumuh di Kota Blitar tersebut memiliki korelasi, tingkat kerapatan bangunan, 
ketidakteraturan pola kavling, dimensi kavling yang jauh dibawah standar, mata pencaharian yang didominasi oleh sektor nonformal menjadi salah satu gambaran kondisi kawasan tersebut. Selain itu, dari segi persampahan, masyarakat di Lingkungan Kerantil memiliki kebiasaan buruk, dimana mayoritas masyarakat membuang sampah pada bantaran sungai. Hal ini menyebabkan kawasan tersebut terlihat kumuh. Sebenarnya terdapat depo sampah pada kawasan tersebut, namun karena lokasinya berada di area Pasar Legi menyebabkan masyarakat lebih memilih membuang sampah di bantaran sungai karena lokasinya yang lebih dekat dengan permukiman warga.

Pemerintah Kota Blitar telah berusaha untuk dapat meningkatkan kualitas pada kawasan tersebut. Hal ini dapat dilihat dari adanya program-program yang diberikan terkait dengan peningkatan kualitas lingkungan kumuh. Program-program yang ada diantaranya adalah Program Penanggulangan Kemiskinan di Perkotaan (P2KP) dan Program Pemberdayaan Masyarakat Kelurahan (PPMK). Namun program-program tersebut belum memberikan hasil yang signifikan terhadap lingkungan permukiman tersebut. Oleh karena itu, perlu dirumuskan kembali penanganan permukiman kumuh yang tepat melalui penentuan infrastruktur prioritas yang harus segera mendapatkan penanganan pada kedua lokasi tersebut.

\section{TINJAUAN PUSTAKA}

Kumuh adalah kesan atau gambaran secara umum tentang sikap dan tingkah laku yang rendah dilihat dari standar hidup dan penghasilan kelas menengah [4]. Penyebab kekumuhan antara lain: dari segi fisik dimana terdapat ganguan yang ditimbulkan oleh unsur - unsur alam seperti air dan udara; dari segi masyarakat dimana terdapat ganguan yang ditimbulkan oleh manusia sendiri. akibat kekumuhan tersebut akan terjadi gejala-gejala antara lain: kondisi perumahan yang buruk, penduduk yang terlalu padat, fasilitas lingkungan yang kurang memadai, dan budaya kumuh masyarakat. Sedangkan kawasan kumuh adalah kawasan dimana rumah dan kondisi hunian masyarakat di kawasan tersebut sangat buruk. Rumah maupun sarana dan prasarana yang ada tidak sesuai dengan standar yang berlaku, baik standar yang kebutuhan, kepadatan bangunan, persyaratan rumah sehat, kebutuhan sarana air bersih, sanitasi maupun persyaratan kelengkapan prasarana jalan, ruang terbuka, serta kelangkapan fasilitas sosial lainnya [4].

Permukiman Kumuh adalah permukiman yang tidak laik huni karena ketidakteraturan bangunan, tingkat kepadatan bangunan yang tinggi, dan kualitas bangunan serta sarana dan prasarana yang tidak memenuhi syarat, sedangkan Perumahan Kumuh adalah perumahan yang mengalami penurunan kualitas fungsi sebagai tempat hunian [5]. Lingkungan permukiman kumuh [6] dapat didefinisikan sebagai berikut:

1. Lingkungan yang berpenghuni padat (melebihi 500 orang per $\mathrm{Ha}$ ),

2. Kondisi sosial ekonomi masyarakat rendah,

3. Jumlah rumahnya sangat padat dan ukurannya dibawah standart,

4. Sarana dan prasarana tidak ada atau tidak memenuhi standar teknis dan kesehatan,
5. Hunian dibangun diatas tanah milik Negara atau orang lain dan diatur perundang undangan yang berlaku.

Timbulnya permukiman kumuh [6] disebabkan karena:

1. Urbanisasi dan migrasi yang tinggi terutama masyarakat berpenghasilan rendah,

2. Sulit mencari pekerjaan,

3. Sulitnya mencicil atau menyewa rumah,

4. Kurang tegasnya pelaksanaan perundang- undangan,

5. Perbaikan lingkungan yang hanya dinikmati oleh para pemilik rumah serta disiplin warga rendah,

6. Semakin sempitnya lahan permukiman dan tingginya harga tanah.

Berdasarkan tentang pengertian kawasan kumuh di atas, dapat diketahui karakteristik kawasan kumuh. Menurut Sinulingga [7] karakteristik permukiman kumuh antara lain:

1. Penduduknya sangat padat antara $250-400 \mathrm{jiwa} / \mathrm{ha}$.

2. Jalan - jalan sempit tidak dilalui oleh kendaraan roda empat.

3. Fasilitas drainase sangat tidak memadai, dan biasanya terhadap jalan tanpa drainase, sehingga apabila hujan kawasan ini mudah tergenang air.

4. Fasilitas pembuangan air kotor/ tinja sangat minim sekali. Diantaranya sering membuang tinjanya ke saluran dekat rumah, atau ke sungai terdekat.

5. Tata bangunan sangat tidak teratur dan bangunan bangunan pada umumnya tidak permanen dan banyak yang darurat.

6. Fasilitas air bersih sangat minim.

7. Pemilik hak terhadap lahan sering tidak legal.

Sedangkan menurut Prasetyo [8] karakteristik permukiman kumuh yang dirangkum dari beberapa ahli adalah sebagai berikut:

1. Kepadatan penduduk yang tinggi $>200 \mathrm{jiwa} / \mathrm{km} 2$

2. Kepadatan bangunan $>110$ bangunan/Ha.

3. Kondisi prasarana buruk (jalan, air bersih, sanitasi, drainase, dan persampahan).

4. Kondisi fasilitas lingkungan terbatas dan buruk, terbangun $<20 \%$ dari luas persampahan.

5. Sebagian besar penduduknya berpenghasilan dan berpendidikan rendah, serta memiliki sistem sosial yang rentan

Pandangan tentang karakteristik permukiman kumuh dari berbagai literatur umumnya hampir sama, lingkungan kumuh yaitu lingkungan permukiman yang kondisi tempat tinggal atau tempat huniannya berdesakan dengan kepadatan penduduk diatas 500 orang/ha, dibangun secara liar diatas tanah Negara, instansi, perorangan, badan hukum atau yayasan, luas rumah tidak sebanding dengan jumlah penghuninya berukuran kurang dari $10 \mathrm{~m}^{2}$, rumah berfungsi sekedar tempat istirahat atau melindungi diri dari panas, dingin, dan hujan, lingkungan dan tata permukiman tidak teratur, bangunan sementara, acak - acakan tanpa perencanaan, prasarana kurang (mck, air bersih, saluran buangan, listrik, gang, lingkungan jorok, dan menjadi sarang penyakit), fasilitas sosial kurang (sekolah, rumah ibadah, balai pengobatan), mata pencaharian penghuni tidak tetap dan usaha non - formal, tanah bukan milik penghuni, pendidikan rendah, penghuni sering tidak tercatat sebagai warga setempat, rawan kebakaran, banjir, dan rawan terhadap penyakit [4]. 
Dari definisi diatas dapat diketahui bahwa kriteria permukiman kumuh digolongkan seperti rumah dengan sarana dan prasarana, fasilitas sosial yang tidak sesuai dengan standar yang berlaku, tingkat kepadatan penduduk, serta dari segi budaya masyarakatnya sendiri.

Kriteria dan indikator kawasan kumuh dapat diidentifikasi melalui 3 (tiga) bagian [9], diantaranya:

1. Identifikasi Permasalahan Kemumuhan (kondisi bangunan, kondisi jalan lingkungan, kondisi drainase lingkungan, kondisi penyediaan air minum, kondisi pengelolaan air limbah, kondisi pengelolaan persampahan, dan kondisi pengamanan kebakaran).

2. Identifikasi Pertimbangan Lain (nilai strategis lokasi, kepadatan penduduk, potensi sosial dan ekonomi, dukungan masyarakat, serta komitmen Pemerintah Daerah).

3. Identifikasi Legalitas Lahan (status lahan, kesesuaian Rencana Tata Ruang, dan persyaratan administrasi bangunan).

Berdasarkan tinjauan pustaka di atas dapat disimpulkan bahwa faktor-faktor yang berpengaruh terhadap kekumuhan antara lain:

1. Kondisi fisik bangunan

2. Kondisi jalan lingkungan

3. Kondisi drainase lingkungan

4. Penyediaan air minum

5. Pengelolaan air limbah

6. Kondisi persampahan

7. Kondisi pengaman kebakaran

8. Ketersediaan ruang terbbuka hijau

9. Peran pemerintah

10. Kondisi sosial

11. Kondisi ekonomi

12. Peran serta masyarakat

13. legalitas

\section{METODA PENELITIAN}

Penelitian ini diawali berdasarkan latar belakang wilayah penelitian yang merupakankan kawasan kumuh di Kota Blitar, tepatnya berada di Lingkungan Kerantil yang telah ditetapkan oleh Kemeterian PU. Kawasan tersebut telah mendapatkan program-program pemerintah untuk menanggulangi permasalahan kekumuhan. Namun dari beberapa program yang telah dilaksanakan masih belum mampu menangani permasalahan kekumuhan di lokasi tersebut. Sehingga untuk menentukan penanganan infrastruktur yang diprioritaskan perlu dilakukan langkahlangkah antara lain: penentuan faktor penyebab kekumuhan dan penentuan infrastruktur yang diprioritaskan penanganannya. Untuk lebih jelas mengenai metodologi penelitian yang dilakukan dapat dilihat pada Gambar 1.

\section{Penentuan Faktor Penyebab Kekumuhan}

Untuk menganalisis penentuan faktor penyebab kekumuhan di kawasan kumuh Lingkungan Kerantil Kota Blitar dilakukan dengan menggunakan teknik analisis Confirmatory Factor Analysis (CFA). CFA adalah alat abalisis statistik yang digunakan untuk menguji unidimensional, validitas, dan reliabilitas model pengukuran yang tidak dapat diukur secara langsung yang dapat menunjukkan operasionalisasi variabel atau konstruk penelitian menjadi indikator-indikatorterukur yang dirumuskan dalam bentuk persamaan dan atau jalur tertentu [10]. CFA dicirikan sebagai berikut [11]:

1. perubahan konstruk laten akan mempengaruhi perubahan pada indikator

2. arah hubungan kausalitas dari konstruk ke indikator

3. antar ukuran indikator diharapkan saling berkorelasi

4. menghilangkan indikator dari model pengukuran tidak akan merubah makna konstruk

5. menghitung adanya kesalahan pengukuran pada tingkat indikator

6. skala skor tidak menggambarkan konstruk

Dari ciri-ciri di atas, maka untuk melakukan analisis CFA diperlukan kajian teori tentang konstruk yang akan diukur. Dari teori tersebut diperoleh konsep teoritis dan defnisi tentang konstruk yang akan diukur dan selanjutnya dapat diidentifikasi imdikator-indikator sebagai refleksi dari konstruk.

Dalam penelitian ini, analisis $C F A$ digunakan karena indikator-indikator tentang permukiman kumuh merupakan indikator yang tidak dapat diukur secara langsung. Oleh karena itu, dengan menggunakan data berdasarkan kuesioner akan dapat diperoleh hasil mengenai faktor penyebab kekumuhan. Langkah-langkah yang dilakukan dalam analisis ini antara lain: merumuskan faktor penyebab kekumuhan berdasarkan tinjauan pustaka, menyebar kuesioner kepada responden terkait faktor penyebab kekumuhan berdasarkan tinjauan pustaka, menguji validitas dan reliabilitas hasil kuesioner, dan menganalisis hasil kuesioner $C F A$ dengan menggunakan program IBM SPSS AMOS sehingga muncul faktor penyebab kekumuhan yang telah terkonfirmasi secara signifikan.

\section{Penentuan Infrastruktur yang Diprioritaskan Penanganannya}

Untuk menganalisis penentuan infrastruktur yang diprioritaskan penanganannya dilakukan dengan menggunakan teknik analisis Service Quality Analysis (Servqual) dan Importance Performance Analysis (IPA). Langkah-langkah yang dilakukan dalam menganalisis tersebut yaitu dengan melakukan penyebaran kuesioner terkait tingkat kepuasan dan tingkat kepentingan/harapan terhadap faktor penyebab kekumuhan di kawasan kumuh Lingkungan Kerantil yang telah terkonfirmasi dengan menggunakan metode pembobotan. Hasil dari kuesioner tersebut untuk selanjutnya diuji validitas dan reliabilitasnya. Setelahhasil kuesioner dinyatakan valid dan reliabel, maka langkah selanjutnya adalah menemukan rata-rata tingkat kepuasan dan tingkat kepentingan/harapan pada masing-masing variabel. Dari masing-masing ratarata tingkat kepuasan dan tingkat kepentingan/harapan, selanjutnya dicari selisihnya. Selisih yang terendah merupakan variabel yang perbedaan antara tingkat kepuasan dan tingkat kepentingannya paling tinggi. Kemudian untuk menentukan prioritasi penanganan dilakukan dengan menggunakan metode IPA dengan menggunakan diagram kartesius. Dari diagram tersebut ditemukan empat (4) kuadran dimana:

- Kuadran I: merupakan faktor atau variabel yang mempengaruhi kepuasan masyarakat. Pada kuadran ini terjadi pengelompokan dimana kepuasan masyarakat rendah sedangkan harapan masyarakat 


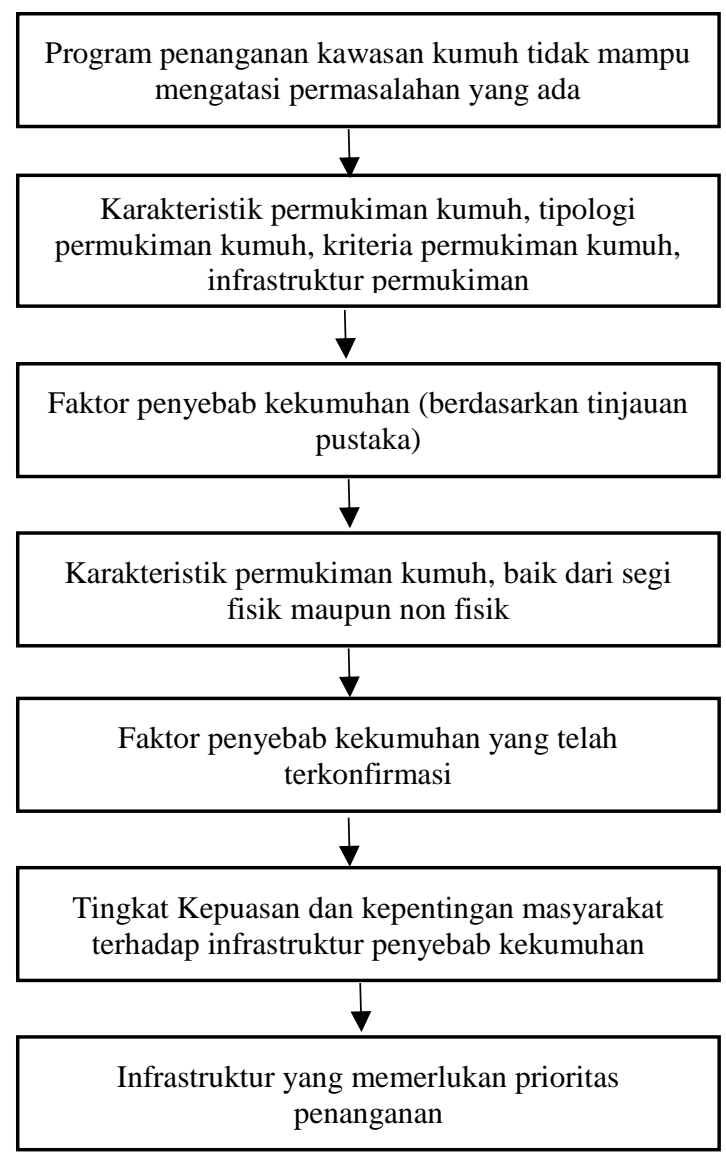

\section{Latar Belakang}

Tinjauan Pustaka

Sintesa Tinjauan Pustaka

Pengumpulan data (kuesioner)

Analisis $C F A$
(berdasarkan kuesioner)

Pengumpulan data (kuesioner servqual)

Analisis Servqual dan IPA

Gambar 1. Bagan Alir Penelitian

tinggi. Untuk itu, pada kuadran ini perlu adanya penanganan yang diprioritaskan

- Kuadran II: merupakan faktor atau variabel yang sangat memuaskan, dimana kepuasan masyarakat tinggi begitu pula dengan kepentingan atau harapannya. Secara umum, faktor atau variabel yang ada pada kuadran ini perlu dipertahankan kondisinya.

- Kuadran III: merupakan faktor atau variabel yang dianggap kurang penting bagi masyarakat. Disamping itu faktor atau variabel yang terdapat pada kuadran ini memiliki nilai tingkat kepuasan yang rendah.

- Kuadran IV: merupakan faktor yang kurang diperhatikan oleh masyarakat, namun dalam pelaksanaannya, faktor tersebut memiliki tingkat kepuasan yang tinggi. Oleh sebab itu perlu mmepertahankan kualitas faktor atau variabel yang ada pada kuadran ini.

\section{PENGUMPULAN DATA}

Untuk melakukan analisis faktor penyebab kekumuhan di Lingkungan Kerantil Kota Blitar serta penanganan infrastruktur prioritasnya diperlukan data primer malalui survei kuesioner pembobotan. Adapun metode sampling yang dilakukan adalah proportional random sampling. Sampling jenis ini dilakukan dengan tujuan untuk mendapatkan data yang merata dari berbagai populasi dalam hal ini RW II, RW III, dan RW VI Kelurahan Sukorejo. Sampel yang digunakan dalam penelitian ini adalah Kepala Keluarga (KK) Lingkungan
Kerantil. Permukiman kumuh tersebut tersebar RW II, RW III, dan RW VI Kelurahan Sukorejo. Jumlah populasi penduduk pada wilayah penelitian ini adalah 4.672 dimana terdapat 1791 jiwa atau 447 KK pada RW II, 1429 jiwa atau 460 KK pada RW III, dan 1452 jiwa atau 452 KK pada RW VI [2]. Untuk menentukan jumlah sampel yang dipakai dalam penelitian ini dengan rumus pengambilan sampel dengan ukuran populasi terhitung menggunakan Rumus Slovin [12].

$$
\mathrm{n}=\frac{N}{N(d)^{2}+1}
$$

Keterangan:

$\mathrm{N}=$ ukuran populasi (KK)

$\mathrm{n}$ = besar sampel yang dibutuhkan (KK)

$\mathrm{d}=$ besaran standar error yang digunakan $(0.1)$

Dengan rumus tersebut, kemudian dimasukkan jumlah Kepala Keluarga (KK) dalam wilayah studi, yaitu sebesar 1.359 dan tingkat error yang diinginkan adalah $10 \%$, maka jumlah sampel yang digunakan dalam penelitian ini adalah:

$$
\begin{aligned}
\mathrm{n} & =1.359 /(1+(1.359 \times 0,01)) \\
& =93.15 \\
& =94
\end{aligned}
$$

Kemudian dengan menggunakan teknik proportional random sampling, dilakukan pembagian proporsi sampel tiap RW agar terjadi pemerataan penyebaran kuesioner pada wilayah penelitian seperti yang ditampilkan pada Tabel 1. 
Tabel 1. Sampel Kuesioner

\begin{tabular}{cccc}
\hline Lokasi & Jumlah KK & Proporsi & Jumlah Sampel \\
\hline RW II & 447 & $33 \%$ & 31 \\
RW III & 460 & $34 \%$ & 32 \\
RW VI & 452 & $33 \%$ & 31 \\
Jumlah & 1.359 & $100 \%$ & 94 \\
\hline
\end{tabular}

Berdasarkan tabel di atas dapat diketahui bahwa jumlah KK pada tiap-tiap RW di Lingkungan Kerantil hamper sama. Oleh karena itu proporsi responden penelitian juga diseimbangkan dengan proporsi jumlah KK yang ada. Oleh karena itu jumlah sampel yang ditentukan adalah 31 responden dari RW II, 32 responden dari RW III, dan 31 responden dari RW VI Lingkungan Kerantil.

Pada pembobotan kuesioner untuk melakukan analisis faktor penyebab kekumuhan di Lingkungan Kerantil Kota Blitar, bobot yang diberikan adalah 1 apabila responden "tidak setuju" bahwa faktor tersebut merupakan faktor penyebab kekumuhan, 2 apabila responden "kurang setuju" bahwa faktor tersebut merupakan faktor penyebab kekumuhan, 3 apabila responden "setuju" bahwa faktor tersebut merupakan faktor penyebab kekumuhan, dan 4 apabila responden "sangat setuju" bahwa faktor tersebut merupakan faktor penyebab kekumuhan. Sedangkan untuk melakukan pembobotan tingkat kepuasan terhadap infrastruktur di Lingkungan Kerantil Kota Blitar, bobot yang diberikan antara lain: 1 apabila responden "tidak puas", 2 apabila responden "kurang puas", 3 apabila responden "puas", dan 4 apabila responden "sangat puas" terhadap infrastruktur di Lingkungan Kerantil Kota Blitar. Begitu pula untuk pembobotan tingkat kepentingan/harapan pembobotan dibagi menjadi 4, diantaranya: 1 apabila responden menganggap infrastruktur tersebut "tidak penting", 2 apabila responden menganggap infrastruktur tersebut "kurang penting", 3 apabila responden menganggap infrastruktur tersebut "penting", dan 4 apabila responden menganggap infrastruktur tersebut "sangat penting".

\section{ANALISIS PENELITIAN}

Kawasan kumuh di Kelurahan Sukorejo Kecamatan Sukorejo Kota Blitar berada di 3unit Rukun Warga (RW) dari 14unit Rukun Warga (RW) yang terdapat di kelurahan tersebut. Wilayah penelitian yang terdapat di 3unit Rukun Warga (RW) tersebut antara lain RW 2, RW 3, dan RW 6 Kelurahan Sukorejo atau yang biasa disebut lingkungan Kerantil. Untuk lebih jelas mengenai lokasi penelitian dapat dilihat pada Gambar 2. Berdasarkan gambar tersebut dapat diketahui bahwa Lingkungan Kerantil dibatasi oleh sungai dan pasar dimana kedua batas tersebut merupakan hal-hal yang berkaitan dengan kekumuhan. Selain itu bila dilihat dari kepadatan bangunan, Lingkungan Kerantil memiliki kepadatan bangunan yang sangat tinggi, dimana terdapat lebih dari $90 \%$ kawasan tersebut merupakan kawasan terbangun.

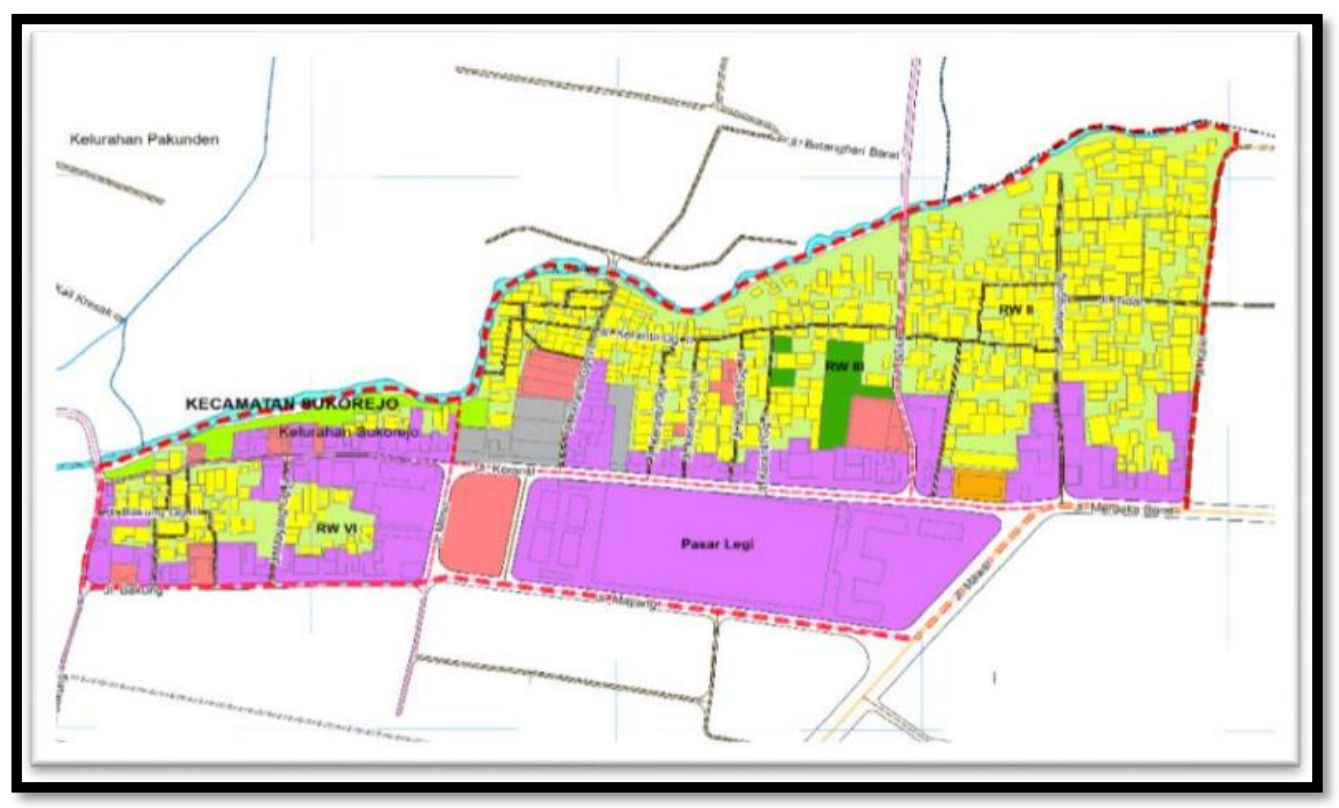

Gambar 2. Peta Wilayah Penelitian

\section{Faktor Penyebab Kekumuhan di Lingkungan Kerantil Kota Blitar}

Berdasarkan kajian pustaka di atas terdapat beberapa faktor penyebab kekumuhan, diantaranya: jaringan jalan (jangkauan jaringan jalan, dimensi jalan, perkerasan jalan, kondisi jalan, dan penerangan jalan lingkungan); saluran drainase (potensi genangan, ketersediaan saluran drainase, sistem drainase, kondisi saluran drainase, dan kualitas konstruksi saluran drainase); jaringan air bersih (suplai air bersih, kondisi air bersih, dan kebutuhan akan air bersih); jaringan air limbah (ketersediaan saluran air kotor, ketersediaan WC, sistem pengelolaan air kotor, dan kondisi 
prasarana dan sarana air kotor); persampahan (prasarana persampahan, sistem pengelolaan persampahan, dan kondisi prasarana dan sarana persampahan), fisik bangunan (ketidakteraturan bangunan, tingkat kepadatan bangunan, kualitas bangunan, dan ketersediaan ruang dalam bangunan); pananggulangan bahaya kebakaran (prasarana proteksi kebakaran, sarana proteksi kebakaran, akses terhadap pelayanan kebakaran); Ruang Terbuka Hijau (ketersediaan RTH publik, ketersediaan RTH privat, dan kondisi RTH); peran pemerintah (penyediaan perumahan layak huni, pembiayaan pembangunan infrastruktur, respon pemerintah); sosial (domisili asal, jumlah penghuni, tingkat Pendidikan, status kependudukan, dan tingkat kekerabatan); ekonomi (jenis pekerjaan, pendapatan perbulan, dan nilai strategis lokasi); peran masyarakat (keinginan masyarakat dalam memelihara lingkungan, keinginan masyarakat dalam meningkatkan kualitas lingkungan, dan kerawanan keamanan); serta legalitas (status kepemilikan lahan dan legalitas bangunan).

Berdasarkan kajian pustaka tersebut untuk selanjutnya dilakukan penyebaran kuesioner pembobotan tentang faktor penyebab kekumuhan tersebut. Setelah data hasil kuesioner diinput, kemudian dilakukan uji validitas dan reliabilitas. Hasil kuesioner dinyatakan valid jika memiliki nilai validitas di atas 0.2028 dan dinyatakan reliabel jika nilai Cronbach's Alpha di atas 0.6. pada tahap selanjutnya dilakukan analisis Confirmatory Factor Analysis (CFA) dengan menggunakan program IBM SPSS AMOS. Pada tahap tersebut dilakukan uji CFA sebanyak dua kali untuk memperoleh variabel yang terkonfirmasi sebagai faktor penyebab kekumuhan di Lingkungan Kerantil Kota Blitar.

Pada uji $C F A$ tahap pertama didapatkan hasil bahwa terdapat beberapa konstruk (untuk selanjutnya disebut dengan variabel) yang memiliki nilai regresi di bawah 0.5 terhadap faktor/indikator. Hal ini menandakan bahwa terdapat hubungan yang rendah antara "variabel" terhadap "faktor" penelitian. Namun untuk dapat mengetahui lebih detail tentang pengaruh yang signifikan antara "variabel" terhadap "faktor" dapat dilihat pada output text. Pada output text terdapat tabel "estimate" yang merupakan tabel yang mampu menginterpretasikan nilai pengaruh "variabel" terhadap "faktor". Pengaruh tersebut ditunjukkan pada kolom "P" dimana pada variabel yang memliki nilai tingkat pengaruh secara signifikan ditunjukkan dengan tanda (***). Sedangkan pada variabel yang tidak memiliki pengaruh secara signifikan dapat dihilangkan pada uji $C F A$ pada tahap 2 karena variabel tersebut merupakan variabel yang tidak berpengaruh secara signifikan terhadap faktor penelitian. Hasil analisis CFA dengan menggunakan program IBM SPSS AMOS dapat dilihat pada Gambar 3 dan Tabel 2.

Dari hasil analisis di atas dapat disimpulkan bahwa variabel yang terkonfirmasi sebagai penyebab kekumuhan antara lain: jangkauan jaringan jalan, dimensi jalan, penerangan jalan lingkungan, ketersediaan saluran drainase, sistem drainase, kondisi saluran drainase, suplai air bersih, kondisi air bersih, kebutuhan akan air bersih, ketersediaan saluran air kotor, ketersediaan WC, sistem pengelolaan air kotor, kondisi prasarana dan sarana air kotor, prasarana persampahan, sistem pengelolaan persampahan, kondisi prasarana dan sarana persampahan, ketidakteraturan bangunan, tingkat kepadatan bangunan, kualitas bangunan, ketersediaan ruang dalam bangunan, prasarana proteksi kebakaran, sarana proteksi kebakaran, akses terhadap pelayanan kebakaran, ketersediaan RTH publik, ketersediaan RTH privat, kondisi RTH, penyediaan perumahan layak huni, pembiayaan pembangunan infrastruktur, respon pemerintah, domisili asal, jumlah penghuni, tingkat Pendidikan, status kependudukan, tingkat kekerabatan, jenis pekerjaan, pendapatan perbulan, keinginan masyarakat dalam memelihara lingkungan, keinginan masyarakat dalam meningkatkan kualitas lingkungan, kerawanan keamanan, status kepemilikan lahan, dan legalitas bangunan. Sedangkan variabel yang tidak terkonfirmasi sebagai penyebab kekumuhan di Lingkungan Kerantil Kota Blitar antara lain: kondisi jalan, perkerasan jalan, potensi genangan, kualitas konstruksi saluran drainase, dan nilai strategis lokasi.

Berdasarkan hasil analisis di atas diperoleh beberapa variabel yang secara signifikan sebagai faktor penyebab kekumuhan yang berupa variabel fisik maupun non fisik. Pengelompokan variabel tersebut dapat dilihat pada Tabel 3. Karena fokus penelitian ini adalah mengenai infrastruktur kawasan kumuh, maka untuk analisis selanjutnya variabel penyebab kekumuhan yang bukan merupakan variabel fisik diabaikan.

\section{Penentuan Infrastruktur yang Diprioritaskan Penanganannya}

Berdasarkan faktor penyebab kekumuhan di Lingkungan Kerantil Kota Blitar yang telah terkonfirmasi, dilakukan analisis penentuan infrastruktur yang diprioritaskan penanganannya. Untuk melakukan analisis tersebut, diperlukan pengelompokan faktor penyebab kekumuhan dengan kategori fisik dan kategori non fisik karena fokus penelitian hanya dibatasi oleh faktor fisik, dalam hal ini infrastruktur. Pengelompokan faktor penyebab kekumuhan dapat dilihat pada Tabel 3. Teknik analisis yang digunakan adalah dengan menggunakan Service and Quality Analysis. Dengan menyebarkan kuesioner pembobotan mengenai tingkat kepuasan dan kepentingan/harapan, dapat dilakukan perhitungan ratarata tingkat kepuasan dan kepentingan/harapan pada masing-masing variabel (setelah dilakukan uji validitas dan reliabilitas). Dari rata-rata pada masing-masing variabel dapat ditemukan selisih antara rata-rata tingkat kepuasan dan tingkat kepentingan/harapan.

Proses analisis ini dilakukan untuk memfasilitasi masyarakat Lingkungan Kerantil terkait pembangunan infrastruktur pada kawasan kumuh sebab program pemerintah yang dijalankan bersifat bottom-up, dimana program-program pemerintah yang dijalankan merupakan program yang diusulkan oleh masyarakat. Dengan mengetahui tingkat kepuasan serta tingkat kepentingan/harapan masyarakat terkait infrastruktur yang perlu mendapatkan penanganan (melalui analisis servqual) diharapkan program pemerintah yang dijalankan sesuai dengan harapan masyarakat.

Berdasarkan hasil analisis servqual di atas, dapat diketahui bahwa terdapat beberapa infrastruktur yang memiliki selisih yang besar antara tingkat kepuasan dan tingkat harapan. Karena semua infrastruktur memiliki selisih yang negatif (-), maka untuk infrastruktur yang diprioritaskan penanganannya adalah infrastruktur yang memiliki tingkat kepuasan di bawah dua (2) yang berarti 
mayoritas responden menyatakan tidak puas terhadap infrastruktur tersebut. Infrastruktur tersebut antara lain: prasarana persampahan (-2.064), kondisi sarana dan prasarana persampahan (-1.787), sistem pengelolaan persampahan (-1.787), ketersediaan RTH publik (-1.723), ketersediaan RTH privat (-1.713), sarana proteksi kebakaran (-1.574), akses terhadap pelayanan kebakaran (1.532), penerangan jalan lingkungan (-1.383), kondisi RTH (-1.362), jangkauan jaringan jalan (-1.330), dan dimensi jalan (-1.309). Untuk lebih jelas mengenai hasil analisis servqual dapat dilihat pada Tabel 4.
Selain itu, untuk menyempurnakan penentuan prioritas dapat dilakukan dengan menggunakan Importance Performance Analysis (IPA). teknik ini selain digunakan untuk menentukan prioritas penanganan, juga digunakan untuk menggolongkan alternatif penanganan. Data yang dilakukan untuk melakukan analisis IPA adalah data nilai rata-rata tingkat kepuasan dan tingkat kepentingan/harapan. Dari analisis yang telah dilakukan dengan menggunakan program IBM SPSS 22 didapatkan hasil seperti pada Gambar 4.

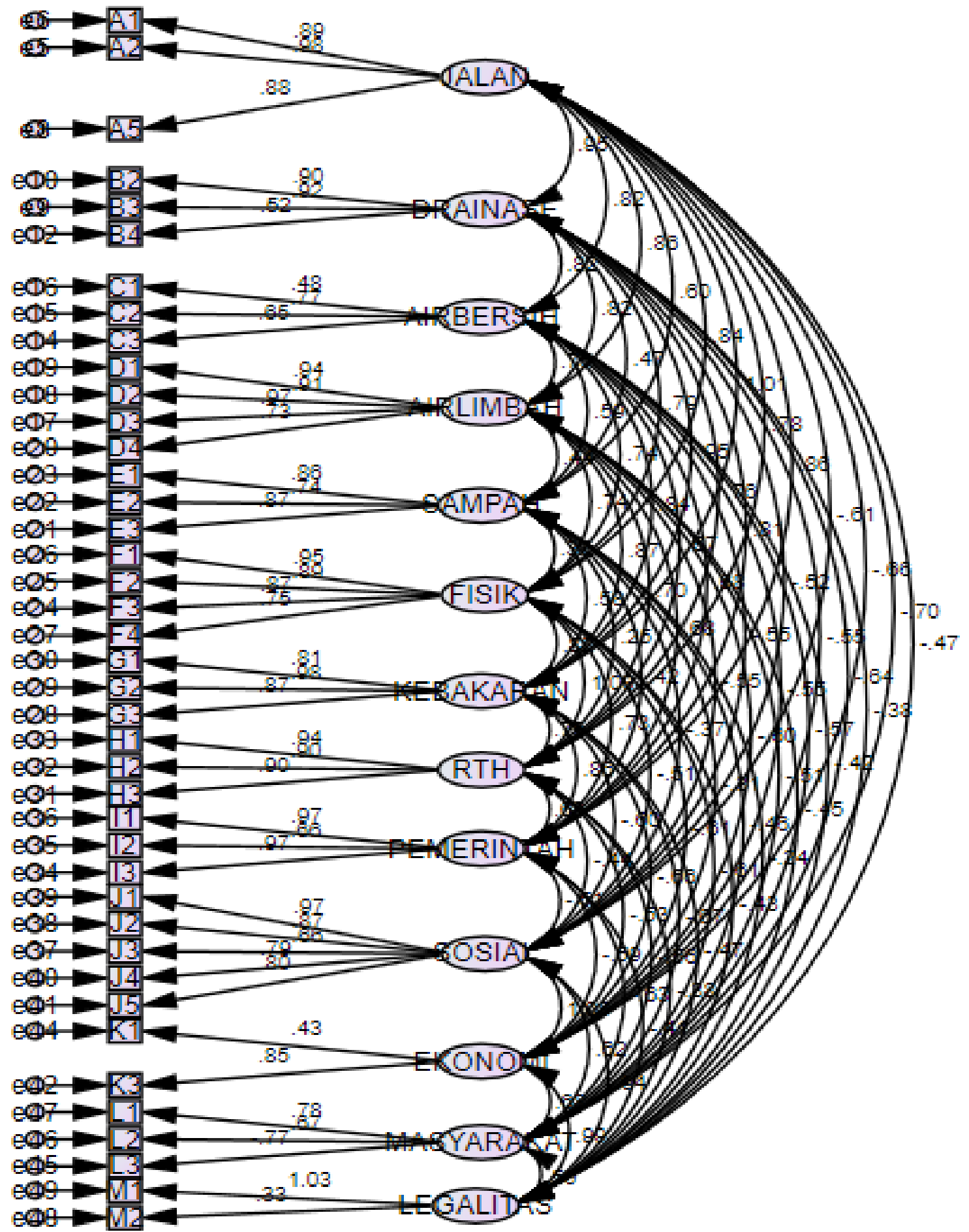

Gambar 3. Diagram Analisis CFA Tahap II 
Berdasarkan gambar di atas dapat diketahui bahwa terdapat beberapa variabel yang telah dihilangkan karena memiliki nilai regresi kurang dari 0.5. variabel yang dihilangkan antara lain: A3 (perkerasan jalan), A4 (kondisi jalan), B1 (potensi genangan), B5 (kualitas konstruksi saluran drainase), dan K2 (nilai strategis lokasi). Sedangkan variabel yang tidak dihilangkan merupakan variabel yang memiliki nilai regresi terhadap faktor penelitian di atas 0.5 .

Tabel 2. Tabel Hasil Uij CFA Tahap II

\begin{tabular}{|c|c|c|c|c|c|c|c|}
\hline & & Variabel & Estimate & S.E. & C.R. & $\mathbf{P}$ & Label \\
\hline A2 & $<---$ & JALAN & 1.208 & .069 & 17.435 & $* * *$ & \\
\hline A1 & $<---$ & JALAN & 1.000 & & & & \\
\hline A5 & $<---$ & JALAN & .939 & .072 & 12.971 & $* * *$ & \\
\hline B3 & $<---$ & DRAINASE & 1.000 & & & & \\
\hline B2 & $<---$ & DRAINASE & 1.135 & .078 & 14.617 & $* * *$ & \\
\hline B4 & $<---$ & DRAINASE & .316 & .057 & 5.558 & $* * *$ & \\
\hline C3 & $<---$ & AIRBERSIH & .781 & .132 & 5.921 & $* * *$ & \\
\hline $\mathrm{C2}$ & $<--$ & AIRBERSIH & 1.000 & & & & \\
\hline C1 & $<--$ & AIRBERSIH & .716 & .165 & 4.348 & $* * *$ & \\
\hline D3 & $<---$ & AIRLIMBAH & 1.000 & & & & \\
\hline D2 & $<--$ & AIRLIMBAH & .816 & .046 & 17.759 & $* * *$ & \\
\hline D1 & $<--$ & AIRLIMBAH & .885 & .043 & 20.508 & $* * *$ & \\
\hline D4 & $<--$ & AIRLIMBAH & .618 & .064 & 9.688 & $* * *$ & \\
\hline E3 & $<---$ & SAMPAH & 1.000 & & & & \\
\hline E2 & $<--$ & SAMPAH & .831 & .102 & 8.125 & $* * *$ & \\
\hline E1 & $<---$ & SAMPAH & .962 & .099 & 9.719 & $* * *$ & \\
\hline F3 & $<--$ & FISIK & 1.000 & & & & \\
\hline F2 & $<---$ & FISIK & .948 & .074 & 12.788 & $* * *$ & \\
\hline F1 & $<--$ & FISIK & 1.344 & .092 & 14.605 & $* * *$ & \\
\hline F4 & $<--$ & FISIK & .733 & .078 & 9.364 & $* * *$ & \\
\hline G3 & $<--$ & KEBAKARAN & 1.000 & & & & \\
\hline G2 & $<--$ & KEBAKARAN & 1.051 & .068 & 15.568 & $* * *$ & \\
\hline G1 & $<--$ & KEBAKARAN & .736 & .070 & 10.532 & $* * *$ & \\
\hline H3 & $<---$ & RTH & .881 & .054 & 16.176 & $* * *$ & \\
\hline $\mathrm{H} 2$ & $<--$ & RTH & .813 & .050 & 16.125 & $* * *$ & \\
\hline H1 & $<---$ & RTH & 1.000 & & & & \\
\hline I3 & $<--$ & PEMERINTAH & 1.000 & & & & \\
\hline 12 & $<--$ & PEMERINTAH & .762 & .093 & 8.154 & $* * *$ & \\
\hline I1 & $<--$ & PEMERINTAH & 1.060 & .043 & 24.417 & $* * *$ & \\
\hline $\mathbf{J 3}$ & $<---$ & SOSIAL & .824 & .109 & 7.587 & $* * *$ & \\
\hline $\mathbf{J} 2$ & $<---$ & SOSIAL & 1.000 & & & & \\
\hline J1 & $<--$ & SOSIAL & 1.025 & .067 & 15.343 & $* * *$ & \\
\hline $\mathrm{J4}$ & $<---$ & SOSIAL & .830 & .084 & 9.836 & $* * *$ & \\
\hline J5 & $<---$ & SOSIAL & .873 & .085 & 10.249 & $* * *$ & \\
\hline K3 & $<--$ & EKONOMI & 2.023 & .425 & 4.761 & $* * *$ & \\
\hline K1 & $<--$ & EKONOMI & 1.000 & & & & \\
\hline L3 & $<--$ & MASYARAKAT & -.928 & .132 & -7.040 & $* * *$ & \\
\hline $\mathbf{L} 2$ & $<--$ & MASYARAKAT & .751 & .123 & 6.101 & $* * *$ & \\
\hline L1 & $<--$ & MASYARAKAT & 1.000 & & & & \\
\hline M2 & $<--$ & LEGALITAS & 1.000 & & & & \\
\hline M1 & $<---$ & LEGALITAS & 2.571 & .824 & 3.118 & .002 & \\
\hline
\end{tabular}

Berdasarkan tabel di atas dapat diketahui bahwa hampir semua variabel penelitian memiliki nilai "P" atau tingkat pengaruh yang signifikan $(* * *)$ dengan toleransi kesalahan 0.001. hanya terdapat satu variabel yang memiliki pengaruh dengan toleransi kesalahan 0.002 . Namun dalam penelitian ini variabel dengan pengaruh yang toleransi kesalahannya 0.002 masih tetap dimasukkan pada variabel yang berpengaruh karena dalam penelitian ini menggunakan toleransi kesalahan 0.005. sehingga berdasarkan analisis $C F A$ dapat dihasilkan bahwa variabel di atas merupakan variabel penyebab kekumuhan di Lingkungan Kerantil Kota Blitar yang telah terkonfirmasi. 
Tabel 3. Pengelompokan Variabel Penyebab Kekumuhan di Lingkungan Kerantil Kota Blitar

\begin{tabular}{|c|c|}
\hline $\begin{array}{c}\text { Variabel Penyebab Kekumuhan Berupa Layanan } \\
\text { Infrastruktur }\end{array}$ & $\begin{array}{c}\text { Vriabel Penyebab Kekumuhan Bukan Berupa } \\
\text { Layanan Infrastruktur }\end{array}$ \\
\hline $\begin{array}{l}\text { Jalan: } \\
\text { - Jangkauan jaringan jalan } \\
\text { - } \quad \text { Dimensi jalan } \\
\text { - } \quad \text { Penerangan jalan lingkungan }\end{array}$ & $\begin{array}{l}\text { Fisik Bangunan } \\
\text { - } \quad \text { Ketidakteraturan bangunan } \\
\text { - } \quad \text { Tingkat kepadatan bangunan } \\
\text { - Kualitas bangunan } \\
\text { - Ketersediaan ruang dalam bangunan }\end{array}$ \\
\hline $\begin{array}{l}\text { Saluran Drainase } \\
\text { - } \quad \text { Ketersediaan saluran drainase } \\
\text { - } \quad \text { Sistem drainase } \\
\text { - } \quad \text { Pemeliharaan saluran drainase }\end{array}$ & $\begin{array}{l}\text { Peran Pemerintah } \\
\text { - Penyediaan perumahan layak huni } \\
\text { - Pembiayaan pembangunan infrastruktur } \\
\text { - Respon pemerintah }\end{array}$ \\
\hline $\begin{array}{l}\text { Air Bersih } \\
\text { - } \quad \text { Suplai air bersih } \\
\text { - } \quad \text { Kondisi air bersih } \\
\text { - Kebutuhan akan air bersih }\end{array}$ & $\begin{array}{l}\text { Sosial } \\
\text { - } \quad \text { Domisili asal } \\
\text { - } \quad \text { Tumlah penghuni } \\
\text { - } \quad \text { Status kependudukan } \\
\text { - Tingkat kekerabatan }\end{array}$ \\
\hline $\begin{array}{l}\text { Air Limbah } \\
\text { - } \quad \text { Ketersediaan saluran air kotor } \\
\text { - } \quad \text { Ketersediaan WC } \\
\text { - } \quad \text { Sistem pengelolaan air kotor } \\
\text { - } \quad \text { Kondisi prasarana dan sarana air kotor }\end{array}$ & $\begin{array}{l}\text { Ekonomi } \\
\text { - Jenis pekerjaan } \\
\text { - Pendapatan perbulan }\end{array}$ \\
\hline $\begin{array}{l}\text { Persampahan } \\
\text { - Ketersediaan prasarana dan sarana persampahan } \\
\text { - } \quad \text { Sistem pengelolaan persampahan } \\
\text { - } \quad \text { Kondisi prasarana dan sarana persampahan }\end{array}$ & $\begin{array}{l}\text { Peran Masyarakat } \\
\text { - Keinginan masyarakat dalam memeilihara } \\
\text { lingkungan } \\
\text { - Keinginan masyarakat dalam meningkatkan } \\
\text { kualitas lingkungan }\end{array}$ \\
\hline $\begin{array}{l}\text { Proteksi Kebakaran } \\
\text { - Prasarana proteksi kebakaran } \\
\text { - Sarana proteksi kebakaran } \\
\text { - } \quad \text { Akses terhadap pelayanan kebakaran } \\
\text { RTH } \\
\text { - Ketersediaan RTH publik } \\
\text { - Ketersediaan RTH privat } \\
\text { - Kondisi RTH } \\
\end{array}$ & $\begin{array}{l}\text { Legalitas } \\
\text { - } \quad \text { Status kepemilikan bangunan } \\
\text { - } \quad \text { Legalitas bangunan }\end{array}$ \\
\hline
\end{tabular}

Berdasarkan analisis $C F A$ yang telah dilakukan dapat diketahui beberapa variabel penyebab kekumuhan di Lingkungan Kerantil Kota Blitar. Variabel tersebut untuk selanjutnya dikelompokkan berdasarkan kategori "infrastruktur" dan "bukan infrastruktur". Pengelompokan ini dilakukan karena dalam analisis selanjutnya fokus penelitian ditujukan pada variabel yang berupa infrastruktur. Berdasarkan tabel di atas dapat diketahui bahwa infrastruktur penyebab kekumuhan di Lingkungan Kerantil antara lain jalan, saluran drainase, air bersih, air limbah, persampahan, proteksi kebakaran, dan Ruang Terbuka Hijau (RTH).

Tabel 4. Hasil analisis servqual

\begin{tabular}{|c|c|c|c|c|c|c|c|}
\hline \multicolumn{2}{|l|}{ Faktor } & \multicolumn{2}{|l|}{ Variabel } & \multirow{2}{*}{$\begin{array}{r}\begin{array}{c}\text { Mean } \\
\text { kepuasan }\end{array} \\
1.957\end{array}$} & \multirow{2}{*}{$\begin{array}{r}\begin{array}{c}\text { Mean } \\
\text { kepentingan }\end{array} \\
\mathbf{3 . 2 8 7}\end{array}$} & \multirow{2}{*}{$\begin{array}{c}\begin{array}{c}\text { Selisish } \\
\text { mean }\end{array} \\
-1.330\end{array}$} & \multirow{2}{*}{$\begin{array}{c}\text { Keterangan } \\
\text { Prioritas }\end{array}$} \\
\hline Jalan & $\mathbf{A}$ & $\begin{array}{l}\text { Jangkauan jaringan } \\
\text { jalan }\end{array}$ & 1 & & & & \\
\hline & & Dimensi jalan & 2 & 1.968 & 3.277 & -1.309 & Prioritas \\
\hline & & $\begin{array}{l}\text { Penerangan jalan } \\
\text { lingkungan }\end{array}$ & 5 & 1.936 & 3.319 & -1.383 & Prioritas \\
\hline \multirow[t]{3}{*}{$\begin{array}{l}\text { Saluran } \\
\text { Drainase }\end{array}$} & B & $\begin{array}{l}\text { Ketersediaan saluran } \\
\text { drainase }\end{array}$ & 2 & 2.074 & 3.255 & -1.181 & - \\
\hline & & Sistem drainase & 3 & 2.106 & 3.277 & -1.170 & - \\
\hline & & $\begin{array}{l}\text { Kondisi sarpras } \\
\text { saluran drainase }\end{array}$ & 4 & 2.840 & 3.266 & -0.426 & - \\
\hline \multirow[t]{2}{*}{ Air bersih } & $\mathrm{C}$ & Suplai air bersih & 1 & 2.883 & 3.309 & -0.426 & - \\
\hline & & kondisi air bersih & 2 & 2.894 & 3.585 & -0.691 & - \\
\hline
\end{tabular}


Sambungan Tabel 4.

\begin{tabular}{|c|c|c|c|c|c|c|c|}
\hline & & $\begin{array}{l}\text { kebutuhan akan air } \\
\text { bersih }\end{array}$ & 3 & 2.904 & 3.309 & -0.404 & - \\
\hline \multirow[t]{4}{*}{ Air limbah } & $\mathrm{D}$ & $\begin{array}{l}\text { Ketersediaan saluran } \\
\text { air limbah }\end{array}$ & 1 & 2.191 & 3.309 & -1.117 & - \\
\hline & & Ketersediaan WC & 2 & 2.851 & 3.319 & -0.468 & - \\
\hline & & $\begin{array}{l}\text { sistem pengelolaan air } \\
\text { kotor }\end{array}$ & 3 & 2.181 & 3.170 & -0.989 & - \\
\hline & & $\begin{array}{l}\text { Kondisi sarpras air } \\
\text { kotor }\end{array}$ & 4 & 2.415 & 3.468 & -1.053 & - \\
\hline \multirow[t]{3}{*}{ Persampahan } & $\mathbf{E}$ & $\begin{array}{l}\text { prasarana } \\
\text { persampahan }\end{array}$ & 1 & 1.372 & 3.436 & -2.064 & Prioritas \\
\hline & & $\begin{array}{l}\text { sistem pengelolaan } \\
\text { persampahan }\end{array}$ & 2 & 1.628 & 3.415 & -1.787 & Prioritas \\
\hline & & $\begin{array}{l}\text { kondisi sarpras } \\
\text { persampahan }\end{array}$ & 3 & 1.702 & 3.489 & -1.787 & Prioritas \\
\hline \multirow[t]{3}{*}{$\begin{array}{l}\text { proteksi } \\
\text { kebakaran }\end{array}$} & G & $\begin{array}{l}\text { prasarana proteksi } \\
\text { kebakaran }\end{array}$ & 1 & 2.362 & 3.500 & -1.138 & - \\
\hline & & $\begin{array}{l}\text { sarana proteksi } \\
\text { kebakaran }\end{array}$ & 2 & 1.968 & 3.543 & -1.574 & Prioritas \\
\hline & & $\begin{array}{l}\text { akses terhadap } \\
\text { pelayanan } \\
\text { kebakaran }\end{array}$ & 3 & 1.947 & 3.479 & -1.532 & Prioritas \\
\hline \multirow[t]{3}{*}{ RTH } & $\mathbf{H}$ & $\begin{array}{l}\text { Ketersediaan RTH } \\
\text { publik }\end{array}$ & 1 & 1.872 & 3.596 & -1.723 & Prioritas \\
\hline & & $\begin{array}{l}\text { Ketersediaan RTH } \\
\text { privat }\end{array}$ & 2 & 1.691 & 3.404 & -1.713 & Prioritas \\
\hline & & Kondisi RTH & 3 & 1.915 & 3.277 & -1.362 & Prioritas \\
\hline
\end{tabular}

Berdasarkan tabel di atas dapat diketahui bahwa beberapa infrastruktur yang diprioritaskan penanganannya adalah infrastruktur yang memiliki tingkat kepuasan di bawah 2 (dua) dengan asumsi bahwa dengan nilai tersebut, responden. Infrastruktur yang mendapatkan prioritas penanganan berdasarkan analisis servqual antara lain: jangkauan jaringan jalan, dimensi jalan, penerangan jalan lingkungan, prasarana persampahan, sistem pengelolaan persampahan, kondisi prasarana dan prasarana persampahan, sarana proteksi kebakaran, akses terhadap pelayanan kebakaran, ketersediaan RTH publik, ketersediaan RTH privat, dan kondisi RTH.

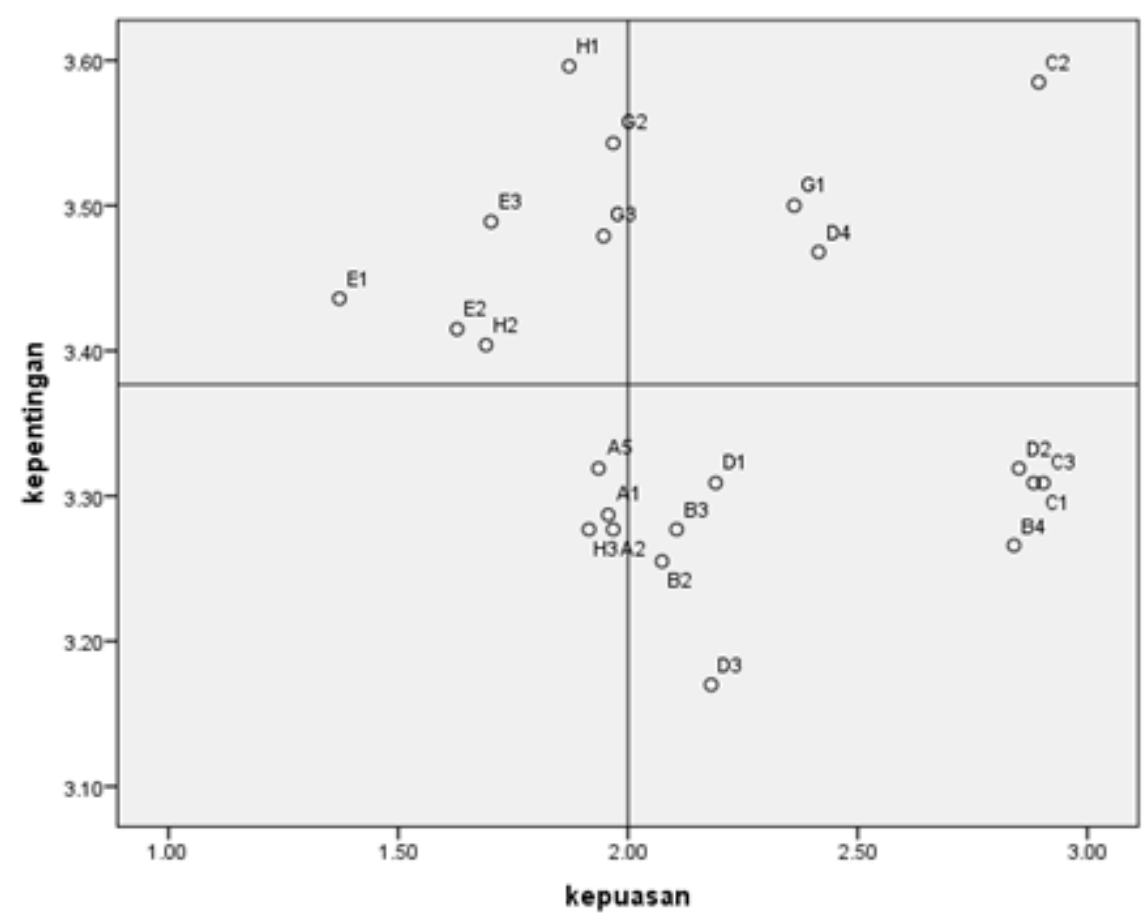

Gambar 4. Diagram Kartesius Tingkat Kepuasan dan Kepentingan 
Berdasarkan gambar di atas dapat dijelaskan bahwa dari analisis IPA yang didapatkan dari nilai rata-rata kepuasan dan kepentingan terhadap infrastruktur dibagi menjadi empat (4) kuadran dimana:

1. Kuadran I: merupakan faktor atau variabel prioritas. Pada kuadran ini terjadi pengelompokan dimana kepuasan masyarakat rendah sedangkan harapan masyarakat tinggi. Untuk itu, pada kuadran ini perlu adanya penanganan yang diprioritaskan

2. Kuadran II: merupakan faktor atau variabel yang memuaskan, dimana kepuasan masyarakat tinggi begitu pula dengan kepentingan atau harapannya. Secara umum, faktor atau variabel yang ada pada kuadran ini perlu dipertahankan kondisinya. Namun pada penelitian ini karena nilai tingkat kepentingan atau harapannya masih lebih tinggi daripada tingkat kepuasan, maka masih diperlukan perbaikan meskipun tidak menjadi priortas penanganan.
3. Kuadran III: merupakan faktor atau variabel yang dianggap kurang penting bagi masyarakat. Disamping itu faktor atau variabel yang terdapat pada kuadran ini memiliki nilai tingkat kepuasan yang rendah. Namun karena nilai tingkat kepentingan atau harapannya masih lebih tinggi daripada tingkat kepuasan, maka masih diperlukan perbaikan sehingga memenuhi tingkat kepuasan msyarakat meskipun merupakan faktor atau variabel yang kurang diperhatikan.

4. Kuadran IV: merupakan faktor yang kurang diperhatikan oleh masyarakat, namun dalam pelaksanaannya, faktor tersebut memiliki tingkat kepentingan yang lebih tinggi. Oleh sebab itu perlu mepertahankan kualitas faktor atau variabel yang ada pada kuadran ini.

Keempat kuadran tersebut dapat dilihat pada Tabel 5.

Tabel 5. Pengelompokan variabel terhadap kuadran IPA

\begin{tabular}{|c|c|c|c|}
\hline No. & Kuadran & Variabel & Kode \\
\hline \multirow[t]{7}{*}{1} & I & prasarana persampahan & E1 \\
\hline & (PRIORITAS) & sistem pengelolaan persampahan & $\mathrm{E} 2$ \\
\hline & & kondisi sarpras persampahan & E3 \\
\hline & & sarana proteksi kebakaran & $\mathrm{G} 2$ \\
\hline & & akses terhadap pelayanan kebakaran & G3 \\
\hline & & Ketersediaan RTH publik & $\mathrm{H} 1$ \\
\hline & & Ketersediaan RTH privat & $\mathrm{H} 2$ \\
\hline \multirow[t]{3}{*}{2} & II & kondisi air bersih & $\mathrm{C} 2$ \\
\hline & & Kondisi sarpras air kotor & D4 \\
\hline & & prasarana proteksi kebakaran & G1 \\
\hline \multirow[t]{8}{*}{3} & III & Ketersediaan saluran drainase & B2 \\
\hline & & Sistem drainase & B3 \\
\hline & & Kondisi sarpras saluran drainase & B4 \\
\hline & & Suplai air bersih & $\mathrm{C} 1$ \\
\hline & & Kebutuhan akan air bersih & $\mathrm{C} 3$ \\
\hline & & Ketersediaan saluran air limbah & D1 \\
\hline & & Ketersediaan WC & D2 \\
\hline & & sistem pengelolaan air kotor & D3 \\
\hline \multirow[t]{4}{*}{4} & IV & Jangkauan jaringan jalan & A1 \\
\hline & & Dimensi jalan & $\mathrm{A} 2$ \\
\hline & & Penerangan jalan lingkungan & A5 \\
\hline & & Kondisi RTH & $\mathrm{H} 1$ \\
\hline
\end{tabular}

Infrastruktur yang diproritaskan berdasarkan tabel di atas antara lain: prasarana persampahan, sistem pengelolaan persampahan, kondisi prasarana dan sarana persampahan, sarana proteksi kebakaran, akses terhadap pelayanan kebakaran, ketersediaan RTH publik, dan ketersediaan RTH privat. Ketujuh infrastruktur tersebut diprioritaskan penanganannya sebab memiliki responden berpendapat bahwa kepuasan terhadap ketujuh infrastruktur tersebut sangat rendah namun kepentingan/harapan terhadap infrastruktur tersebut sangat tinggi. Terdapat beberapa perbedaan untuk penentuan infrastruktur yang diprioritaskan berdasarkan analisis sebelumnya, dimana infrastruktur jangkauan jalan, dimensi jalan, penerangan jalan lingkungan, dan kondisi RTH merupakan infrastruktur yang diprioritaskan. Namun pada analisis IPA ini, keempat infrastruktur tersebut bukan menjadi prioritas sebab berdasarkan nilai rata-rata kepentingan/harapannya, responden menilai keempat infrastruktur tersebut memiliki nilai dibawah nilai rata-rata kepentingan/harapan terhadap seluruh infrastruktur yang memerlukan penanganan.

\section{KESIMPULAN}

Kekumuhan kawasan pada Lingkungan Kerantil Kota Blitar dipengaruhi oleh beberapa faktor, diantaranya faktor jalan, saluran drainase, jaringan air bersih, jaringan air kotor, persampahan, fisik bangunan, proteksi pemadam kebakaran, Ruang Terbuka Hijau (RTH), peran pemerintah, sosial, ekonomi, peran masyarakat, dan legalitas. Dari berbagai macam faktor penyebab kekumuhan tersebut terdapat beberapa infrastruktur yang diprioritaskan untuk segera mendapatkan penanganannya, diantaranya infrastruktur persampahan (prasarana persampahan, sistem pengelolaan persampahan, kondisi prasarana dan sarana persampahan), proteksi pemadam kebakaran (sarana proteksi kebakaran dan akses terhadap 
pelayanan kebakaran), dan ketersediaan RTH (ketersediaan RTH publik dan ketersediaan RTH privat).

Untuk penyempurnaan penelitian, perlu dilakukannya penelitian mengenai penanganan infrastruktur persampahan di Lingkungan Kerantil. Selain itu untuk meningkatkan kualitas lingkungan di Lingkungan Kerantil Kpta Blitar diperlukan adanya upaya nyata terkait penanganan infrastruktur penyebab kekumuhan di Lingkungan Kerantil Kota Blitar secara terus menerus agar Lingkungan Kerantil Kota Blitar mampu terbebas dari lingkungan kumuh.

CATATAN. Makalah ini merupakan bagian dari Tesis yang disusun oleh penulis pada Program Magister Manajemen Aset Infrastruktur, Departemen Teknik Sipil, ITS Surabaya yang bekerjasama dengan Program Karyasiswa Kementerian Pekerjaan Umum dan Perumahan Rakyat.

\section{DAFTAR PUSTAKA}

[1] Budihardjo, Eko. (1997). Sejumlah Masalah Permukiman Perkotaan. Bandung: Alumni

[2] Pemerintah Kota Blitar. (2017). Profil Kelurahan Kota Blitar Tahun 2016. Kota Blitar.

[3] Pemerintah Kota Blitar. (2015) Penyusunan Perencanaan Inventarisasi Infrastruktur Kecamatan Sukorejo. Kota Blitar
[4] Kurniasih, Sri. (2007). Usaha Perbaikan Permukiman Kumuh Di Petukangan Utara - Jakarta Selatan. Tesis. Teknik Arsitektur Universitas Budi Luhur.

[5] UU 1/2011. Undang-undang nomor 1 tahun 2011 tentang Perumahan dan Kawasan Permukiman.

[6] Khomarudin. (1997). Menelusuri Pembangunan Perumahan dan Permukiman. Jakarta: Yayasan Real Estate Indonesia, PT. Rakasindo.

[7] Sinulingga, B.D. (2005), Pembangunan Kota, Tinjauan Regional dan Lokal. Jakarta: Pustaka Sinar Harapan.

[8] Prasetyo, Hari. (2013). Karakteristik Permukiman Kumuh:

https://www.scribd.com/doc/186673148/Karakteristi k-Dan-Kriteria-kawasan-Kumuh-hariprasetyo.

[9] Permen PUPR 2/2016. Permen PUPR no.2/prt/m/2016 tentang Peningkatan Kualitas Terhadap Perumahan Kumuh Dan Permukiman Kumuh.

[10] Kusnendi. (2008). Model-Model Persamaan Struktural. Bandung: Alfabeta.

[11] Ghozali, Imam, (2008), Model Persamaan Struktural Konsep dan Aplikasi dengan Program Amos 16.0. Semarang: Badan Penerbit UNDIP.

[12] Sarwono, Jonathan. (2006). Metode Penelitian Kuantitatif. Yogyakarta: Graha Ilmu. 